\title{
UCRL-- 15514
}

DE83 004309

\section{UCRL-15514 \\ $S / C 5299101$ \\ cot-830406--2}

CENTRAL-CELL BLANKET-MODULE-

MAINTENANCE APPROACH FOR THE MARS HIGH-

TEMPERATURE BLANKET

TRW, INC.

December 1982

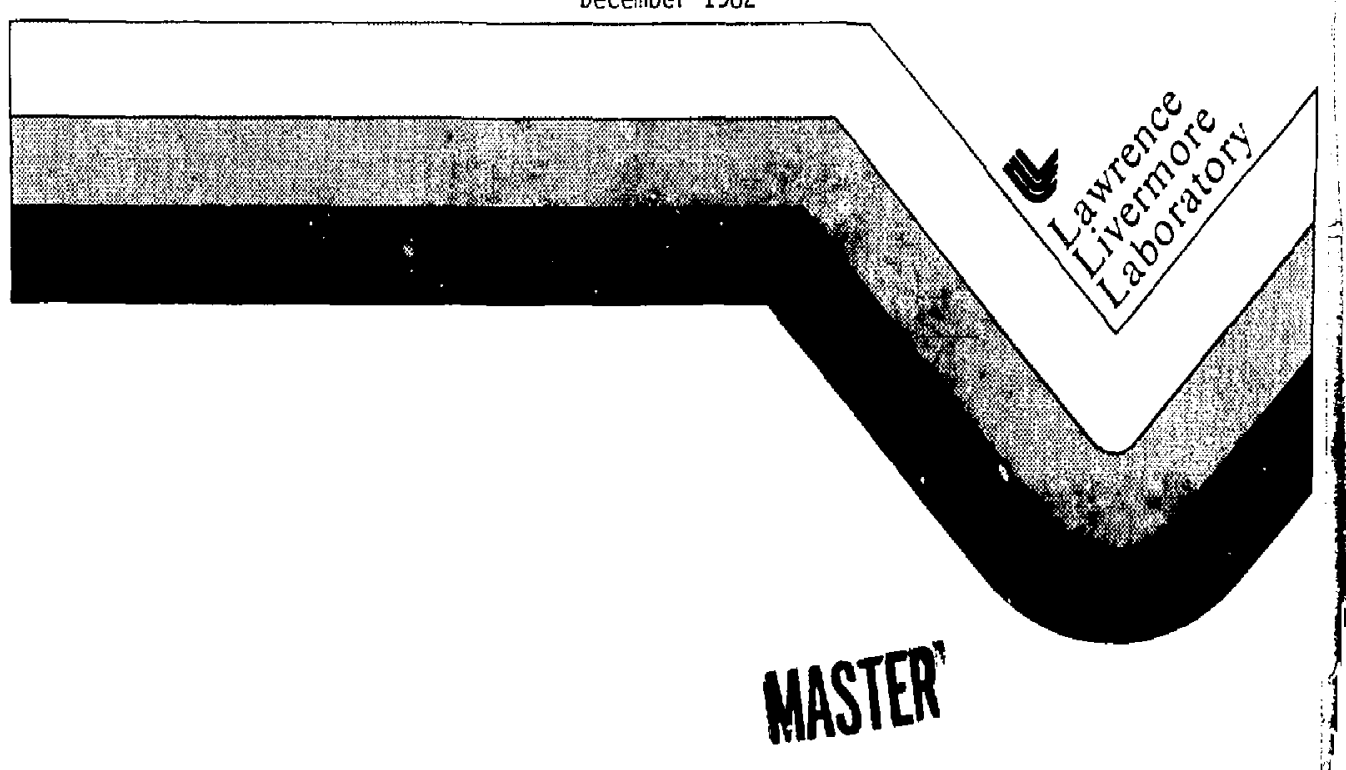

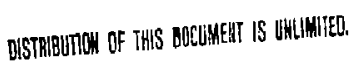


Work performed ueder the aupices of the 1.S.

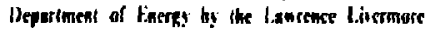

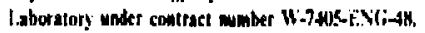

This document was prepured as an account of nork sponsured by an apency of the linied Siates Cioncrnmem. Neither the l'nited States lovernment nor any opency tbereof, nor any of their employess, makes any narranty, txpressed or impliked, or ansumes any lezal liability of respomsibility for the accuraç. com. plecenest. or usefulness of amy information, apparatus, product, or procens disclosed, or represents then its use would not infringe prixately onned rights. Reference herein to any specific cummercial product, process, or scrvice hy trade nanic, trademurk. manufacturter, or othernive, does mot necessarily constitutc of injply its endonement, recommendation, or favoriag by the $I^{\prime} n$. ilted Sistes dinternment or any agensy thereul. The tisns and opinions of authers expressed herein do nal meremurily state of reflect those of the linited States Cotcrnment or any agency thereof. 
CEITRAL CELL BLANRET MODULE

MAINTENANCE APPROACH FOR THE MARS

EIGH TEMPRATURE BLANKET

N, Youdg, Ebasco Services; D. Sutliff, D. Talt, R. Stebert, J. Coulahan, General Dynamies; J. R. Garner, J. D. Gordon, TRW Energy Development Group

The objectives of the blanket module maintenance systems on MARS is to oninimize anchine down teme for normal and off-normal events while safely removing and replacing the blanket modules. Remote, manual, and automited handiling wethods will be used depending on rad1ation levels and the tesk. Since blanket replacement is a yearly maintenance operation, considerable effort is being expended to design the modules and module handing systers for rapid removal and replacement. The use of remote techniques increase the time required to perform any task. While good component design for remote handling can lessen the antentenance tioe, it connot compare with normal manual servicing. Therefore, it is prudent to maxisize the number of operations that can be performed "hands-on". By selectively increasing the shielding in certain high maintenuce areas, waintenance time can be zeduced. The machine wallability is maximized by woving amall aumber of large lntegral units on a fixed rail or roller system. The number of operations, thefr complexity and the cost of equipment is also reduced. This techrique has been used successfully in shipbulldIng programs to decrease construction time. All central cell components ore designed for rapid replacement. Fallure of any component, including - central cell wuperconducting magnet, wlll not result in excessive downtime.

The general maintenance philosophy for replacement of wodules is reviewed in this paper. This includes a discussion of the method for disassembly of the spent nodule in a hot bay area. An Initial equipment requirements 1 lot is developed to apport the malntenance approach.

In general, blanket module components weighing several mundred tons of less vill be handled with on overhead (gantry) crone. Items in excess of this weight will be woved on track or roller bystem specifically designed for and incorporated into the Whis facility. Use of geveral robile trunsporters will eldoinace the need to have a transport systert bulit 1nto each of the 24 modules. This results in considerable cost avings and reduced achine complexity. Such aysten requires that access to vodules must be provided. Consequently, ervice Ilnes, the in coolant piplog, buc systems and all service lines wust epproach the uchine from one asde and frow the top of the achine. Disconnection and ake up of these conections if a candidate for hands 0 n malntenance.

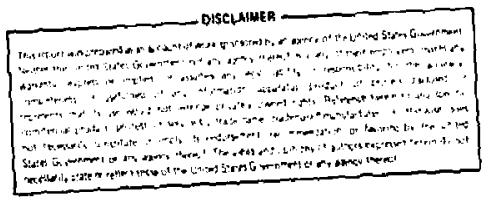


Structural components removed from within the modules will be highly activated. These structures must be prepared for shipment off site in shielded containers or for on-site storage. High level waste requiring off-site storage will probably be compacted to peroit easler and more economical packaging. It may also be possible to dilute vastes for on-site low level storage. To accomplish this, a waste preparation area has been proposed for the mantenance area. This area would be equipped to further disassemble and cut up the activated structures by totally remote means. A packaging and package decontantination area will also be provided.

\section{Acinowleòment}

This work was funded under LLWL Contract No. 5299101. 
Technical Information Deparment - Lawrence Livermore Laboratory University of California - Livermore. California 94550

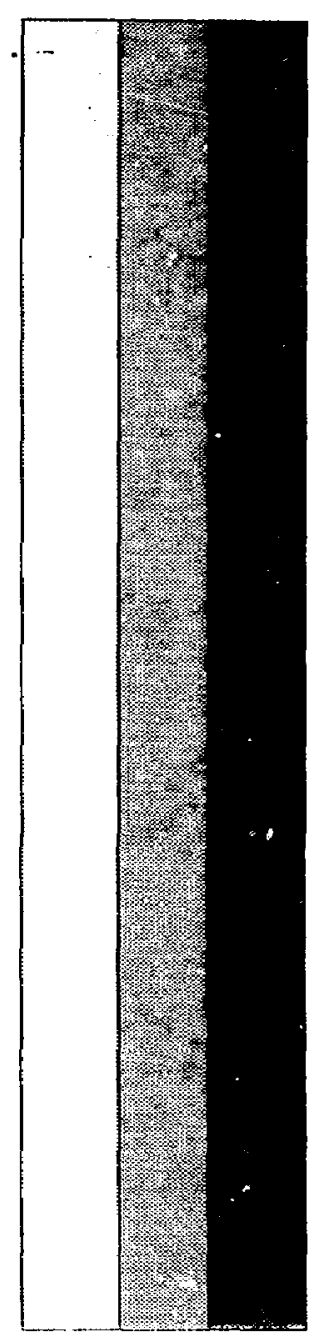

